Discussion Paper No. 598

THE SOURCES OF GROWTH AT DIFFERENT LEVELS OF DEVELOPMENT

\author{
Evan Osborne
}

October 2003

The Institute of Social and Economic Research

Osaka University

6-1 Mihogaoka, Ibaraki, Osaka 567-0047, Japan 


\title{
The Sources of Growth at Different Levels of Development
}

\author{
Evan Osborne \\ Wright State U. Dept. of Economics and Osaka U. Institute of Social and Economic \\ Research \\ 3640 Col. Glenn Hwy. \\ Dayton, OH 45435 \\ (937) 7754599 \\ (937) 7752441 (Fax) \\ evan.osborne@,wright.edu
}




\begin{abstract}
$\underline{\text { Abstract }}$
Cross-country growth regressions have become an increasingly common tool in empirical development research. But these regressions typically do not attempt to distinguish among countries in different stages of development. Two empirical methods are used to test for such differences. Several of the factors known to affect economic growth are shown to operate differently for countries in different portions of the global income distribution. The results have implications for the role of financial markets, openness and human capital in promoting growth.
\end{abstract}


What separates wealthy nations from poor ones is one of the cornerstones of economic theory. ${ }^{1}$ But it has only been in recent years, with the development of powerful computational techniques and data sets, that empirical analysis of growth and why it happens (or, more revealingly, does not happen) has taken off. A common technique in this analysis has been cross-country regressions in which national economic performance, typically growth in per capita product, has been used as the dependent variable. Among the pioneering work in this regard is Barro (1991). The technique has also been applied to investigate derivative issues such as foreign aid (Burnside and Dollar,2000) and the effects of an open economy (Sachs and Warner, 1995; Rodriguez and Rodrik, 2001).

Yusuf and Stiglitz (2001) lay out what we know about achieving modernization in light of this empirical revolution, which they refer to as the "settled issues" in development economics. Among them are the importance of physical and human capital accumulation (including not just education but knowledge available nonrivalrously to all and produced by activities such as scientific research), low inflation, open trade, clean governance, secure property rights, flexible labor markets and provision of social safety nets. Other issues, e.g. the role of industrial policy, remain unsettled.

But a tacit assumption of much of this empirical growth literature, as well as the aforementioned theoretical consensus, is catholicity - the notion that whatever the sources of growth, in empirical testing the processes that create it ought to be assumed to operate identically in all countries, be they highly advanced or pre-industrialized. The

1. For example, in a letter to David Ricardo in 1817 Thomas Malthus is reported to have said that the question of development is "the grand object of all enquiries in Political Economy" (Landes, 1999). 
growth process is assumed to be the same in Sweden as it is in Bangladesh, with only parameter values distinguishing the two. Typically this assumption plays out when data from all nations are thrown into a single regression, which is then subjected to a single estimation technique at all levels of per capita income.

This paper investigates whether the findings of the growth literature are common to countries at different levels of per capita income. The findings provide some insight with respect to proper sequencing of reforms when political constraints exist, and explain some of the stylized facts of development and the politics of international trade. Section I describes the problem and some of the controversies in the literature its resolution might address, Sections II and III contain the empirical results, and Section IV analyzes the findings.

\section{Growth nonlinearities}

The approach bears some similarity to Barro (2000). There is a production function that relates potential output to a vector of inputs. At the same time, societies face constraints, imposed by government or beyond their control, that limit the efficiency of input conversion, and hence cause output to fall short of the production frontier. To the extent that these constraints are the results of policy choices, such choices thus have costs that may or may not be worthwhile, but must be accounted for in assessing growth. Actual output is then some transformation of available resources, e.g. schooling and physical capital, and the choices that have been made or the constraints that are faced with respect to macroeconomic management, political stability and so on. 
An issue of interest is whether the resources available and the choices made have different effects at different levels of this function. Government spending, for example, is sometimes both in theory (Krichel and Levine, 2001) and empirically (Barro, 2000; Barro, 1991; Tavares and Wacziarg, 2001) shown to be negatively related to growth. Do advanced societies more frequently fall into the trap of factional warfare over government spoils to such an extent that they cripple the economy's productive capacity (Olson, 1982)? Or is there a rent-seeking trap visible in government spending (or in economic distortions) that tends to affect the poorest countries most (Krueger, 1974)? Is human capital something that provides the most critical payoffs in the earliest stages of takeoff, or is it a resource that causes the richest countries to further distance themselves from poorer ones, owing to the increasing returns to scale and spinoffs it generates, in combination with the tendency of richer countries to invest more in human capital than poorer ones (Bils and Klenow, 2000)? Adverse international developments might be thought to affect poorer countries most substantially because richer countries tend to have more complex, diverse economies, so that it is easier to insure against such developments. Standard growth regressions, with their one-size-fits-all assumption about the relation between growth and various independent variables, are incapable of resolving such questions. In addition, the empirical approach in this paper can address the absence of convergence by poorer countries to the income levels of the wealthiest ones. The absence of such convergence has been a continuing mystery because it contradicts a central prediction of the standard Solow (1956) growth model. 


\section{Income as the dependent variable}

To get a better handle on such questions, a first empirical model is developed that is somewhat different from those in much of the growth literature. That work typically has growth over some interval as the dependent variable, and either the beginning or the average values over the interval of the exogenous variables. But while that approach is adequate to the task of investigating whether high-growing countries behave differently from slowly growing ones, the question here is whether rich countries respond differently to the exogenous variables from poor ones. Hence, the first tactic is to use the absolute level of per capita GDP rather than growth as the dependent variable. It, like all variables unless otherwise noted, comes from the updated Barro-Lee data set. The productive factors other than labor are assumed to be the country's capital stock and its human capital, as outlined below. Indeed, often the growth literature uses a flow (per capita GDP growth) both as the dependent variable and for physical capital (the investment-toGDP ratio) but uses a stock for human capital. Here, both factor variables are expressed as stocks, with per capita income taken as the flow output of these factor inputs plus the institutional, political and other factors that limit the productive power of those factors. The base regression for this alternative specification, takes the following form:

$$
\begin{aligned}
& \text { PCGDP }=a_{0}+a_{1} \text { KAPW }+a_{2} \text { HUMCAP }+a_{3} \text { INFLATION }+a_{4} \text { DEMOCRACY } \\
& +a_{5} \text { GOVT }+a_{6} \text { TERMS }+a_{7} \text { LIQUID }+a_{8} \text { INSTABILITY } \\
& +a_{9} \text { OPEN }+a_{10} \text { PREMIUM }
\end{aligned}
$$


$P C G D P$ and $K A P W$ are per capita GDP and non-residential capital per worker. $K A P W$ comes from the Penn World Tables v. 5.6. HUMCAP is the country's population's contemporaneous average schooling. HUMCAP and $K A P W$ are thus the productive factors available. The other right-hand variables are familiar from the existing empirical growth literature. INFLATION, GOVT, and INSTABILITY and are, respectively, the average annual rate of inflation, of government consumption less education and defense spending as a percentage of GDP, and of the Barro/Lee measure of political instability during the previous five-year period. DEMOCRACY is the lagged Barro (2000) measure of democracy. PREMIUM is the lagged logarithm of (1+BMP), where $B M P$ is the black-market premium on the country's exchange rate, which is often used as a proxy for the amount of government distortion in the economy. TERMS is the change during the previous five-year period in the country's export to import relative prices. OPEN is the average openness of the economy during the previous five years as defined by Sachs and Warner (1995). LIQUID is the average during the previous fiveyear period of liquid liabilities to GDP. This variable might proxy either for the sophistication of a country's financial markets, which has drawn a great deal of attention after the villainous role in which they were cast in some accounts of the 1997 East Asian crash, or the extent of public and private indebtedness.

But a simple OLS or panel regression would not enable an answer to the questions outlined above. An alternate approach is to employ the quantile-regression technique of Armstrong et al. (1979). Quantile-regression coefficients are estimated to minimize the sum of absolute values of errors, rather than the sum of squared errors. More importantly for the problem here, coefficients can be estimated to minimize the sum of absolute error 
values relative to a particular point in the sample distribution of the left-hand variable. In particular, for a quantile $q$ of the dependent variable the coefficients minimize

$$
\sum_{i=1}^{n}\left(y_{i}-\beta x_{i}\right) a_{i}
$$

where $a_{i}=2 q$ if the residual is positive and $2(1-q)$ otherwise. The resulting coefficient estimates thus can be interpreted as the marginal impact of a change in one of the righthand variables for an observation at the quantile $q$ in the distribution of the left-hand variable. Here, the regression line will be fitted through various quantiles of the sample distribution of per capita GDP. The regressions are calculated using Stata/SE 7.0, which calculates coefficient standard errors via bootstrapping methods.

Table 1 presents the results of a standard median regression of (1), i.e. a regression line through $q=0.5$. In contrast to regressions that take growth as the dependent variable, measuring the extent to which constraints detract from the ability of a given stock of factors to produce income yields somewhat different results. The two productive factors are strongly significant, as would be required in almost any modern theory of growth, but the only other variables that are significant are DEMOCRACY and OPEN. Table 1 also presents, for comparison, OLS results. In addition to the previously significant variables, TERMS is significant in the expected positive direction, and $G O V$ is also significant with a negative sign.

But employing the quantile-regression technique reveals subtleties in the results. Table 2 presents the results of the estimations of (1) for the $0.2,0.4,0.6$ and 0.8 quantiles. The two factor coefficients are statistically significant at at least the ten-percent level 
throughout. DEMOCRACY is significant in three out of the four quantiles $(0.2,0.6,0.8)$, with a positive sign. LIQUID is significant with a positive sign in the 0.2 and 0.4 quantiles, $O P E N$ at $0.2,0.6$ and 0.8 and PREMIUM at 0.4 .

To test whether growth effects differ at different levels of development is to ask whether the differences in these coefficients are statistically significant. The test for the null that the difference between any two coefficients for the right-hand variable $j$ in the quantiles $q$ and $r, x_{j q}-x_{j r}$, is zero is distributed $F(1, n-k-1)$, where $k$ is the number of right-hand variables. Table 3 lists the associated $p$-values for the right-hand variables used in (2) for the 0.2 and 0.8 quantiles. The differences in four of the coefficients HUMCAP, TERMS, LIQUID and OPEN - are significant at at least the ten-percent level. A finding of immediate interest is that $H U M C A P$ has a significantly higher coefficient at the 0.8 than at the 0.2 quantile.

In addition, TERMS has a higher effect on gross domestic product for higher levels of GDP, as does OPEN. These effects are not surprising in and of themselves, in that the wealthier economies generally have more factor endowments per capita, and thus the cost of a given amount of economic mismanagement or disturbance will be absolutely higher. However, LIQUID has a coefficient that declines continuously as one moves up from the 0.2 to the 0.8 quantiles. This is a result that is difficult to interpret cleanly, depending as it does on what LIQUID is measuring, but it does suggest that welldeveloped financial markets are perhaps most critical for the poorest nations, even though such countries are of course the places where financial markets are typically the leastdeveloped. 
The coefficients in Table 2 with statistically significant differences at the 0.2 and 0.8 quantiles are in bold. In each case the coefficient pattern is monotonic as the quantile index increases. This consistency is on its own evidence of some nonlinearities in the development process. $H U M C A P$ and $O P E N$ have coefficients that increase continuously from the 0.2 to 0.8 quantiles. This indicates that human capital is more productive for richer than for poorer countries, and that openness is also more beneficial as countries get wealthier, at least in absolute terms. Note, however, that in percentage terms the effects may be significantly greater for the poorest countries. Table 4 lists the values of the 0.2 , 0.4, 0.6 and 0.8 quantiles for the left-hand variable $P C G D P$, and the proportion of the quantile coefficients from Table 2 as a percentage of these quantile values. These represent a crude estimate of the proportionate effect on income (i.e., the growth boost or drag) of a marginal increase in the variables in question for each stage of the global income distribution. In the case of each of these two variables the percentages decline, but the decline is significantly steeper for $H U M C A P$. Thus, an argument can be made that human-capital is in absolute terms more important for the wealthiest nations, but in percentage terms more important for the poorest nations. This in turn allows the inference that schooling improvements are a key part of whatever convergence exists. Similarly, a failure to invest in human capital may be disastrous for the ability to catch up. As for openness, somewhat surprisingly at first blush the effects are quite large in a relative sense for wealthier countries. However, if one believes in endogenousgovernance theory (Becker, 1983), then this finding would explain the stylized fact, visible both in cross-sectional contemporaneous government attitudes toward free-trade negotiations and in the behavior of countries like Germany, Britain and the U.S. over the 
course of the industrialization process, that richer countries tend to be more enthusiastic advocates of free trade. Richer countries at a moment in time tend to be more enthusiastic promoters of openness, and countries that successfully industrialize tend to move toward more openness unilaterally and to advocate it more strongly for others than they did in earlier stages of their own development.

TERMS has a consistently increasing coefficient. This is somewhat surprising when compared to much of the conventional wisdom, at least in popular commentary, about the relation between poverty and international economic developments. It is often assumed that the poorest nations, often heavily dependent on commodities, are most vulnerable to adverse price movements. Supposedly, they are almost totally dependent on a small number of highly volatile commodity exports, as well as being heavily reliant on importation to acquire many complex manufactured goods. One would expect that terms-of-trade shocks would have the greatest effect on such countries.

In fact, consistent with the previous two variables there is a significant decline in the percentage effect of TERMS (along with a relatively flat absolute effect) at the 0.2 , 0.4 and 0.6 quantiles. But there is a substantial increase in the effect for the wealthiest countries. Evidently, in the later stages of industrialization nations tend to become significantly more dependent on trade. Whether that is because of greater export dependence on frontier industries that are not produced in poorer countries, from productlifecycle effects or for some other reason is unclear, but the urgency of openness for the most advanced economies is a striking finding, and has interesting implications for the politics of international-trade negotiations. 
The final variable to have a statistically significant coefficient difference is LIQUID. The finding of a declining coefficient throughout can be interpreted in two ways. If LIQUID, as it is often assumed to, measures the maturity of a country's financial markets, then the results suggest that the greatest impact is felt in the poorest countries. This is a result of substantial importance with respect to the question of financing industrialization via banks versus capital markets, as well as whether foreign portfolio capital should be allowed into the poorest countries. Evans, et al. (2002), among others, support the importance of financial development in promoting growth even after taking account of human capital. The results here add to that by indicating that this effect is greatest even in absolute (let alone proportionate) terms for the poorest countries. If LIQUID is interpreted as indebtedness, then a high value in poor countries could imply significant borrowing to fund high-return modernization investment opportunities no longer available in mature economies. Similar high debt in the latter might indicate profligacy rather than the aggressive accumulation of capital. It is of course possible that LIQUID proxies for both phenomena at the same time, with the latter effect coming to dominate in mature economies, where financial markets are already fully developed, requiring a greater value of $L I Q U I D$ to indicate some other phenomenon.

\section{Growth as the dependent variable}

It is also possible to test for different effects at different points of the sample distribution of per capita income by employing interaction terms in a more conventional growth regression. In that case the left-hand variable is the per capita growth rate rather 
than the level of per capita GDP. The following equation, standard in growth regressions, is estimated as a panel model:

$$
\begin{aligned}
& \text { GROWTH }=b_{0}+b_{1} \text { INVGDP }+b_{2} \text { HUMCAP }+b_{3} \text { INFLATION }+b_{4} \\
& \text { DEMOCRACY }+b_{5} \text { GOVT }+b_{6} \text { TERMS }+b_{7} \text { LIQUID }+b_{8} \text { INSTABILITY } \\
& +b_{9} \text { OPEN }+b_{10} \text { PREMIUM }+b_{11} \text { PCGDP }+b_{11} \text { INTER }
\end{aligned}
$$

GROWTH is average growth in per capita gross domestic product at 1985 international prices over a five-year period. INFLATION, DEMOCRACY, GOVT, TERMS, LIQUID, PREMIUM, OPEN, and INSTABILITY are similar to their definition in (1) except that they are the averages for the contemporaneous period rather than the previous one. HUMCAP is the level of average schooling at the beginning of the interval. Rather than using the stock of capital as a determinant of growth, capital accumulation is measured by inclusion of INVGDP, the five-year average of investment as a percentage of GDP. $P C G D P$ is per capita gross domestic product, whose presence is designed to test for neoclassical convergence. In an ordinary regression, $P C G D P$ should for a given level of constraints have a negative sign, as the higher is per capita income the closer a nation is to the technological frontier and the more slowly it should grow. INTER is a general prefix for variables in which $P C G D P$ is interacted with the other right-hand variables.

To test the performance of random-effects and fixed-effects models, Table 5 reports the estimations of (2) without interaction terms by both techniques. The performance of the random-effects model is clearly superior, and so for the interaction 
models these are the only results that are reported. The results for this basic regression are in agreement with many cross-country regression empirical models. Government consumption, the black-market premium, and instability have a negative effect, as does inflation, which is not typically included in such work. Investment, favorable developments in the terms of trade, and openness have a positive effect. Schooling has a positive effect, which just fails to pass muster at the ten-percent level of significance ( $p<$ 0.106). Per capita gross domestic product is negatively signed, as the neoclassical growth model predicts.

As for interaction terms, in the results listed in Table 6 two of them are statistically significant, with signs the same as in the previous model. INTERPREMIUM is significant with a negative sign, suggesting that government distortions do more damage to the growth rate in poorer than in richer countries. And INTERHUMCAP has a positive sign, so that richer countries get more economic growth in percentage terms out of a given amount of population education than poorer ones. While INTEROPEN and INTERDEM are not significant, they do have the predicted signs and do approach statistical significance $(p<0.165$ and $p<0.168$ respectively). Of particular interest is the absence of significance for INTERINV. Diminishing returns in a static Solow production function would suggest that this coefficient would have a negative sign, as the growth achieved by adding capital is exhausted. The results suggest instead that innovation, spillover from education or some other factor means that capital stock, at least as it is measured in the Penn World Tables, does not meaningfully suffer from a diminishingreturns problem. Such knowledge accumulation would counteract the natural 
diminishing-returns properties of physical capital by raising its marginal productivity, and would satisfy the Solow notion of technological progress..

\section{Other Implications}

Table 7 summarizes the findings with respect to statistical significance for both regressions, for the variables that are common to both models. The criteria for inclusion are statistical significance in at least two of the quantiles or a statistically significant difference between the coefficients for the 0.2 and 0.8 quantiles.

\section{Resource efficiency versus resource accumulation}

Initially the differences between the results for the level and growth rate of per capita income are worth noting. The essence of a neoclassical production function augmented by human capital is confirmed by the significance and sign of $K A P W$ and $I N V G D P$ in, respectively, the income and growth equations, along with $A V G S C H O O L$. The variables that are and are not significant after accounting for the level of factors provide an interesting interpretation relative to other literature in the growth literature. It is possible to distinguish between two sources of growth-destroying effects. One effect discourages the accumulation of productive factors, which has for decades been considered a critical part of the industrialization process. This would amount to lesser amounts of $K A P W$ and $A V G S C H O O L$. The other sort of inefficiency causes the existing factor stocks to be used more or less inefficiently, so that a given amount of factor stocks yields less output. This will show up as variables taking statistical significance in the income regressions after factor amounts are accounted for. 
Thus, the significant and substantially positive effect of openness and democracy on income after taking account of factor amounts suggests that these two variables allow resources to be used more efficiently. Elementary comparative-advantage theory provides a straightforward explanation for the first variable. Countries exposed to international commerce will use resources to greater effect than countries that protect. As for democracy, the interpretation is somewhat more ambiguous. One possibility is the controversial and oft-studied hypothesis of Wittman (1989), which argues that democracy is the most efficient form of governance because it amounts to more competitive political markets. The efficiency is defined relative to general voter preferences over all objects of choice rather than income per se, but it is surely conceivable that fewer restraints on overall economic performance would be one, and perhaps a substantial, object of such preferences.

\section{The importance of human capital}

The most robust result is the increasing effect of human capital as one moves up the standard-of-living distribution. There is an increasing absolute though not relative effect in the income regression, and a positive interaction effect on the growth rate in Section III. This is an important result in that it supports the notion that human capital, at least to the extent that schooling proxies for it, is an important factor in continuously raising an economy's potential. Despite the rediscovery of the importance of human capital as a source for growth in Romer (1986), Lucas (1988) and the rest of the newgrowth literature, some work (Hendricks, 2002, Bils and Klenow, 2000) has downplayed its importance. But the results here provide some nuance to the existing theories of 
human capital and development. Given the consistency across both estimation techniques, schooling in particular if not human capital in general has greater effects on richer than on poorer countries.

This is a result that holds equal parts promise and peril. Peril, because it suggests that the absence of convergence may be a recurring problem absent massive injections of human capital into poorer countries. If richer countries continually increase their advantage in human capital over poorer ones by greater investments in it, then it may be even more difficult for poor countries to close the gap. Promise, because even if it is difficult a remedy - substantially higher investments in human capital in poorer countries - suggests itself immediately. While the optimism of those - e.g., Page (1994) - who argue that human capital improvements will help bring about substantial convergence may be misplaced with respect to the difficulty of the task, optimism with respect to its efficacy if accomplished is supported by the results here.

In addition, the evidence is relatively good that openness has positive effects throughout the distribution. In absolute terms the effects of openness seem to increase for richer nations. In percentage terms the effect is somewhat greater for the poorest nations. Unlike human capital, the remedy for openness is administratively very simple, if not necessarily politically so. If one is giving advice to political authorities with at least some freedom of movement, then openness should loom large in the recommendations made. Recall that the analysis of the first estimation combined with endogenous-governance theory suggests that richer countries will often find openness in their own interest. 
The agreement of the two models with respect to TERMS is noteworthy. There is a widespread belief that poorer nations are more vulnerable to adverse developments in international commerce. Indeed, the "small open economy" is a pillar of development modeling. The basic stereotype has it that these countries tend to depend heavily on commodity or, sometimes, manufactured exports to the industrial world, and thus when commodity prices decline or industrial-country growth slows, the effect on these nations is magnified significantly. In fact, the results suggest that wealthier countries are more sensitive, at least in absolute-dollar terms, to terms-of-trade developments.

With a moment's reflection, the finding should perhaps not be surprising. Contrary to the image of trade-dependent poor countries, Table 8 suggests that in fact wealthier nations depend more on foreign trade than poorer ones. The top portion depicts data from the Penn World Tables v. 6.1 for exports plus imports as a percentage of GDP in 2001 for the $0.2,0.4,0.6$ and 0.8 percentiles of the distribution of real per capita GDP in 2000 . The poorest countries in 2001 , those with per capita GDP of less than $\$ 1589.20$, had a ratio of 0.6282 , while those with a per capita income higher than $\$ 14,589.78$ had a ratio of 0.9880 . Richer countries trade relatively more, and thus ought to be more vulnerable to changes in their terms of trade, other things equal.

This notion of relatively high poor-country vulnerability to international developments is further undermined by examining changes in TERMS as a function of PCGDP. The bottom portion of Table 8 shows the average value of TERMS for 19901995, with the sample again stratified at the same percentile boundaries. While the very poorest countries had the worst average shocks during this period, the 0.2-0.4 group had the best, with a positive average change in terms of trade. Over the entire Barro-Lee 
sample, there is a weakly positive correlation between PCGDP and TERMS, with $\rho=$ $0.0785(p<0.05)$. But in general, from the perspective of the effect of shocks to international relative prices, there does not appear to be any clear connection between place in the global income distribution and damage from global trade developments, and some reason for concluding the opposite.

Finally, the significance of DEMOCRACY in the lowest quantile of the income regressions is perhaps modest evidence against the dismal theory of democracy that has gained some currency in recent years (Zakaria, 2003; Kaplan, 2000; Cheung, 1998). Unalloyed democracy in the absence of the cultural infrastructure of liberal societies, as well as few limits on what democratically elected legislative majorities are allowed to do, is said to enable the worst, most predatory human instincts to take flight and thus destroy not just growth but social stability itself. But DEMOCRACY is statistically significant and positively signed at the lowest levels of the distribution as well as higher ones in the quantile regressions, although there is no evidence that the effect is more powerful in absolute terms for poorer nations. However, even assuming equal effects in absolute terms the proportionate effects in poor countries may well be much greater. While the absence of significance in the interaction regression means that the positive effects of democracy in poor countries, famously recounted by Sen (1981), are not overwhelmingly supported, at a minimum the predatory, pessimistic theories of democracy are rejected.

\section{Conclusion}

There do appear to be some differences over the income distribution with respect to the determinants of growth. These differences are most compelling with respect to 
education and openness. The failure to converge can be attributed to failures to invest in human capital (or at least schooling), and wealthy countries appear to benefit most from openness. In addition, there is some evidence for varying effects with respect to the terms of trade and governmental distortions. And one of the two estimation techniques is consistent with a hypothesis that well-developed financial markets are important to help a poor country take off.

It would be surprising if it were otherwise. The division of labor, the extent of markets and the microeconomic information they reveal, legal structure, engagement with the world and a myriad of other details relevant to growth and prosperity are substantially different in countries in Europe, North America and East Asia than in Africa, Latin America and South Asia. Abstraction is an indispensable tool in advancing the frontiers of knowledge, but like everything it is subject to diminishing returns. It was probably too much to hope for that a single, simple production function would be sufficient to describe the growth process in societies as different as those we see. At the same time, further understanding of those differences may allow the design of better development policy, avoiding some of the mistakes of the past that assumed a uniform set of problems requiring a single solution.

In addition, the results may point the way toward further research on proper sequencing of reforms in economies where many problems must be solved. Openness, evidently, is a reform that carries great benefits for the very poorest countries even as it is administratively straightforward. Similarly, human capital seems to be of singular importance, at least in proportional terms. In decades past physical capital accumulation was seen as the key to prosperity, but the findings here provide more support for an 
approach that emphasizes the need to accumulate human capital.

\section{References}

Armstrong, Ronald D., Frome, E.L., and Kung, D.S. "Algorithm 79-01: A

Revised Simplex Algorithm for the Absolute Deviation Curve Fitting Problem."

Communications in Statistics, Simulation and Computation, B8 (2). New York: Marcel

Decker, 1979, 175-90.

Barro, Robert J. Determinants of Economic Growth: A Cross-Country Empirical

Study. Cambridge, MA: MIT Press, 2000.

Barro, Robert J. "Economic Growth in a Cross-Section of Countries.” Quarterly

Journal of Economics 106 (2), May 1991, 407-443.

Becker, Gary S. "A Theory of Competition Among Pressure Groups for Political

Influence." Quarterly Journal of Economics 98 (3), August 1983, 371-400.

Burnside, Craig and Dollar, David. "Aid, Policies and Growth." American

Economic Review 90 (4), September 2000, 847-868.

Bils, Mark and Klenow, Peter J. "Does Schooling Cause Growth?" American

Economic Review 90 (5), December 2000, 274-280.

Cheung, Steven N.S. "The Curse of Democracy as an Instrument of Reform in

Collapsed Communist Economies." Contemporary Economic Policy 16 (2), April 1998, 247-249.

Evans, Alun Dwyfor, Green, Christopher J., and Murinde, Victor. "Human Capital and Financial Development in Economic Growth: New Evidence Using the Translog Production Function." International Journal of Finance and Economics 7 (2), April 2002, 123-40. 
Hendricks, Lutz. "How Important Is Human Capital for Development? Evidence from Immigrant Earnings." American Economic Review 92 (1), March 2002, 198-219.

Kaplan, Robert. "Was Democracy Just a Moment?" In Robert Kaplan, The Coming Anarchy: Shattering the Dreams of the Post Cold War. New York: Random House, 2000, 59-79.

Krichel, Thomas and Levine, Paul. "The Dynamics of Growth and Fiscal Policy." Scandinavian Journal of Economics 103 (2), June 2001, 295-316.

Krueger, Anne O. "The Political Economy of the Rent-Seeking Society." American Economic Review 64 (3), June 1974, 291-303.

Landes, David S. The Wealth and Poverty of Nations: Why Some are So Rich and Some so Poor. New York: W.W. Norton, 1998.

Lucas, Robert E. Jr. "On the Mechanics of Economic Development." Journal of Monetary Economics 22 (1), July 1988, 3-42.

Olson, Mancur. The Rise and Decline of Nations: Economic Growth, Stagflation, and Social Rigidities. New Haven: Yale University Press, 1982.

Page, John M. "The East Asian Miracle: An Introduction." World Development, 22 (4), April 1994, 615-625.

Rodriguez, Francisco and Rodrik, Dani. "Trade Policy and Economic Growth: A Skeptic's Guide to the Cross-National Evidence." NBER Macroeconomics Annual 2000. Cambridge: MIT Press, 2001, 261-325.

Romer, Paul M. "Increasing Returns and Long-Run Growth." Journal of Political Economy 94 (5), October 1986, 1002-1037. 
Sachs, Jeffrey and Warner, A. "Economic Reform and the Process of Global Integration.” Brookings Papers on Economic Activity, 0 (1), 1995, 1-118.

Sen, Amartya. Poverty and Famines: An Essay on Entitlement and Deprivation. Oxford: Clarendon Press, 1981.

Solow, Robert M. "A Contribution to the Theory of economic Growth." The Quarterly Journal of Economics 70 (1), February 1956, 65-94.

Tavares, Jose and Wacziarg, Romain. "How Democracy Affects Growth.” European Economic Review 45 (8), August 2001, 1341-1378.

Wittman, Donald. "Why Democracies Produce Efficient Results." Journal of Political Economy 97 (6), December 1989, 1395-424.

Yusuf, Shahid and Stiglitz, Joseph E. "Development Issues: Settled and Open." In Gerald M. Meier and Joseph E. Stiglitz (eds.), Frontiers of Development Economics: The Future in Perspective. Washington, The World Bank, 2000, 227-268.

Zakaria, Fareed. The Future of Freedom: Illiberal Democracy at Home and Abroad. New York: W.W. Norton, 2003. 
Table 1

Median regression, per capita income as dependent variable

\begin{tabular}{|c|c|c|}
\hline \multicolumn{2}{|c|}{ Variable } & Coefficient \\
\hline \multirow{2}{*}{\multicolumn{2}{|c|}{ CONSTANT }} & -561.8331 \\
\hline & & $(-1.05)$ \\
\hline \multirow{2}{*}{\multicolumn{2}{|c|}{$K A P W$}} & $0.2064341 * * *$ \\
\hline & & $(11.92)$ \\
\hline \multirow{2}{*}{\multicolumn{2}{|c|}{ HUMCAP }} & $420.4742 * * *$ \\
\hline & & $(78.45306)$ \\
\hline \multirow{2}{*}{\multicolumn{2}{|c|}{ INFLATION }} & -707.0079 \\
\hline & & $(-1.31)$ \\
\hline \multirow{2}{*}{\multicolumn{2}{|c|}{ DEMOCRACY }} & $958.4864 * *$ \\
\hline & & $(2.02)$ \\
\hline \multirow{2}{*}{\multicolumn{2}{|c|}{ GOVT }} & -3110.622 \\
\hline & & $(-1.40)$ \\
\hline \multirow{2}{*}{\multicolumn{2}{|c|}{ TERMS }} & 2102.984 \\
\hline & & $(0.94)$ \\
\hline \multirow{2}{*}{\multicolumn{2}{|c|}{ LIQUID }} & 961.1991 \\
\hline & & $(1.58)$ \\
\hline \multirow{2}{*}{\multicolumn{2}{|c|}{ OPENNESS }} & $843.7941 * *$ \\
\hline & & $(2.51)$ \\
\hline \multirow{2}{*}{\multicolumn{2}{|c|}{ PREMIUM }} & -344.6247 \\
\hline & & $(-0.91)$ \\
\hline \multicolumn{3}{|c|}{$R^{2}: \quad 0.7321$} \\
\hline$N:$ & \multicolumn{2}{|l|}{$\begin{array}{l}0.7321 \\
214\end{array}$} \\
\hline Note: & \multicolumn{2}{|c|}{$\begin{array}{l}* \text { denotes significance at the ten-percent level. } \\
* * \text { denotes significance at the five-percent level. } \\
* * * \text { denotes significance at the one-percent level. }\end{array}$} \\
\hline
\end{tabular}


Table 1 (continued)

OLS regression, per capita income as dependent variable

\begin{tabular}{|c|c|}
\hline Variable & $\underline{\text { Coefficient }}$ \\
\hline$\overline{C O N S T A N T}$ & $\begin{array}{l}-796.4741 * \\
(-1.67)\end{array}$ \\
\hline$K A P W$ & $\begin{array}{l}0.1832118 * * * * \\
(12.32)\end{array}$ \\
\hline$H U M C A P$ & $\begin{array}{l}492.1253 * * * * \\
(68.82155)\end{array}$ \\
\hline INFLATION & $\begin{array}{l}-626.496 \\
(-1.23)\end{array}$ \\
\hline DEMOCRACY & $\begin{array}{l}1459.35 * * * * \\
(3.56)\end{array}$ \\
\hline GOVT & $\begin{array}{l}-3992.995 * * \\
(-1.98)\end{array}$ \\
\hline TERMS & $\begin{array}{l}3757.837 * \\
(1.91)\end{array}$ \\
\hline LIQUID & $\begin{array}{l}524.2403 \\
(0.99)\end{array}$ \\
\hline OPENNESS & $\begin{array}{l}940.583 * * * * \\
(3.21)\end{array}$ \\
\hline PREMIUM & $\begin{array}{l}-410.8241 \\
(-1.11)\end{array}$ \\
\hline $\begin{array}{ll}R^{2}: & 0.9036 \\
N: & 214\end{array}$ & \\
\hline
\end{tabular}


Table 2

Quantile regression, per capita income

Quantile

Variable
CONSTANT
KAPW
HUMCAP
INFLATION
DEMOCRACY
GOV
TERMS
LIQUID
INSTABILITY
OPENNESS
PREMIUM
$R^{2}$
$N$

20

$-1226.731^{*}$
$.2182572^{* * * *}$
$\mathbf{2 1 7 . 7 1 0 3 *}$
60.3768
$631.3259^{*}$
243.5417
$\mathbf{1 7 1 5 . 7 2}$
$\mathbf{2 5 5 9 . 5 0 3 * *}$
$\mathbf{- 8 1 2 . 8 9 2 4}$
$\mathbf{4 9 8 . 2 7 7 *}$
-547.6386
0.6284
214

60

$\begin{array}{lll} & & \\ & & \\ -909.4372 * & -121.6807 & 63.90375 \\ .22582 * * * * & .2271579 * * * * & .2109841 * * * * \\ \mathbf{3 5 1 . 7 1 3 6} * * * * & \mathbf{3 6 6 . 2 9 0 4} * * * & \mathbf{4 7 9 . 1 9 3 5 * * * *} \\ -269.5202 & -841.2787 & -492.9678 \\ 654.5446 & 878.7279 * & 1048.76 * \\ -1034.914 & -3225.528 & -3103.941 \\ \mathbf{1 2 5 7 . 8 0 7} & \mathbf{1 5 9 1 . 6 6 7} & \mathbf{7 7 0 9 . 6 9 3 * *} \\ \mathbf{1 5 1 5 . 6 7 8} * & \mathbf{3 9 2 . 0 2 9 7} & \mathbf{- 3 3 6 . 2 9 4 6} \\ -915.4862 & -729.2297 & 523.5452 \\ \mathbf{5 1 6 . 4 0 5 8} & \mathbf{1 1 7 0 . 4 7 4 * *} & \mathbf{1 7 4 2 . 6 7 5} * * * \\ -529.0416 * * & -400.5238 & -247.4111 \\ 0.7090 & 0.7413 & 0.7413 \\ & & \end{array}$

80 


\section{Table 3}

$p$ values, .20 and .80 quantiles

$\begin{array}{lll}\text { Variable } & X^{2} & p \text {-value } \\ \text { KAPW } & 0.04 & 0.85 \\ \text { AVGSCHOOL } & 3.43 & 0.0654 \\ \text { INFLATION } & 0.27 & 0.6061 \\ \text { DEMOCRACY } & 0.50 & 0.4790 \\ \text { GOV } & 1.05 & 0.3068 \\ \text { TERMS } & 4.51 & 0.0349 \\ \text { LIQUID } & 9.05 & 0.0030 \\ \text { INSTABILITY } & 1.37 & 0.2432 \\ \text { OPEN } & 8.40 & 0.0042 \\ \text { PREMIUM } & 0.33 & 0.5682\end{array}$


Table 4

Percentage effects of quantile coefficients

Quantile values (per capita GDP)

$\begin{array}{ll}0.2 & 816.60 \\ 0.4 & 1570.60 \\ 0.6 & 2916.40 \\ 0.8 & 6807.20\end{array}$

Coefficients/quantile values

HUMCAP

$0.2 \quad 0.267$

$0.4 \quad 0.223$

$0.6 \quad 0.126$

$0.8 \quad 0.070$

OPENNESS

$0.2 \quad 0.610$

$0.4 \quad 0.329$

$0.6 \quad 0.401$

$0.8 \quad 0.256$

TERMS

$0.2 \quad 2.101$

$0.4 \quad 0.801$

$0.6 \quad 0.546$

$0.8 \quad 1.133$

LIQUID

$0.2 \quad 3.134$

$0.4 \quad 0.965$

$0.6 \quad 0.134$

$0.8 \quad-0.049$ 
Table 5

Basic growth regression, fixed and random effects

\begin{tabular}{|c|c|c|}
\hline Variable & $\underline{\text { Fixed effects }}$ & $\underline{\text { Random Effects }}$ \\
\hline CONSTANT & $\begin{array}{l}0.0530635 * * * * \\
(4.00)\end{array}$ & $\begin{array}{l}0.0293929 * * * * \\
(5.16)\end{array}$ \\
\hline$I N V G D P$ & $\begin{array}{l}0.0567861 \\
(1.44)\end{array}$ & $\begin{array}{l}0.0859588 * * * * \\
(3.86)\end{array}$ \\
\hline HUMCAP & $\begin{array}{l}-0.0023464 \\
(-1.01)\end{array}$ & $\begin{array}{l}0.0015898 \\
(1.62)\end{array}$ \\
\hline INFLATION & $\begin{array}{l}-0.0282204 * * * \\
(-2.66)\end{array}$ & $\begin{array}{l}-0.0256605 * * * * \\
(-3.50)\end{array}$ \\
\hline DEMOCRACY & $\begin{array}{l}-0.0076354 \\
(-1.01)\end{array}$ & $\begin{array}{l}0.0000331 \\
(0.01)\end{array}$ \\
\hline$G O V$ & $\begin{array}{l}0.0416894 \\
(0.78)\end{array}$ & $\begin{array}{l}-0.1055809 * * * * \\
(-4.53)\end{array}$ \\
\hline TERMS & $\begin{array}{l}0.0625473 * * * \\
(2.64)\end{array}$ & $\begin{array}{l}0.0807883 * * * * \\
(3.57)\end{array}$ \\
\hline LIQUID & $\begin{array}{l}-0.0191694 \\
(-1.27)\end{array}$ & $\begin{array}{l}-0.0068543 \\
(-1.01)\end{array}$ \\
\hline INSTABILITY & $\begin{array}{l}-0.0195017 * \\
(-1.92)\end{array}$ & $\begin{array}{l}-0.018558 * * \\
(-2.32)\end{array}$ \\
\hline OPENNESS & $\begin{array}{l}0.011293 \\
(1.45)\end{array}$ & $\begin{array}{l}0.0179489 * * * \\
(4.68)\end{array}$ \\
\hline PREMIUM & $\begin{array}{l}-0.011382 * * \\
(-1.98)\end{array}$ & $\begin{array}{l}-0.0110383 * * * \\
(-2.65)\end{array}$ \\
\hline$P C G D P$ & $-0.00000499 * * * *$ & $-0.00000443 * * * *$ \\
\hline$R^{2}$ & 0.0311 & 0.3719 \\
\hline$F$ & $10.56^{* * * *}$ & $\mathrm{~N} / \mathrm{A}$ \\
\hline$X^{2}$ & $\mathrm{~N} / \mathrm{A}$ & $231.49 * * * *$ \\
\hline
\end{tabular}


Table 6

Growth equation, interaction effects

\begin{tabular}{|c|c|c|c|c|}
\hline Variable & Coefficients & & & \\
\hline$\overline{C O N S T A N T}$ & $\begin{array}{l}0.0294214 * * * * \\
(04.36)\end{array}$ & $\begin{array}{l}0.0340182 * * * * \\
(5.39)\end{array}$ & $\begin{array}{l}0.0291521 * * * * \\
(5.07)\end{array}$ & $\begin{array}{l}0.0340783 * * * * \\
(5.11)\end{array}$ \\
\hline$I N V$ & $\begin{array}{l}0.0859038 * * * \\
(2.95)\end{array}$ & $\begin{array}{l}0.0999748 * * * * \\
(4.20)\end{array}$ & $\begin{array}{l}0.0865625 * * * * \\
(3.87)\end{array}$ & $\begin{array}{l}0.0948079 * * * * \\
(4.06)\end{array}$ \\
\hline HUMCAP & $\begin{array}{l}0.0015866 \\
(1.60)\end{array}$ & $\begin{array}{l}0.0001417 \\
(0.11)\end{array}$ & $\begin{array}{l}0.0016042 \\
(1.63)\end{array}$ & $\begin{array}{l}0.001453 \\
(1.45)\end{array}$ \\
\hline INFLATION & $\begin{array}{l}-0.0256627 * * * * \\
(-3.49)\end{array}$ & $\begin{array}{l}-0.0228742 * * * \\
(-3.02)\end{array}$ & $\begin{array}{l}-0.02237^{*} \\
(-1.79)\end{array}$ & $\begin{array}{l}-0.0237326 * * * \\
(3.16)\end{array}$ \\
\hline DEMOCRACY & $\begin{array}{l}0.0000412 \\
(0.01)\end{array}$ & $\begin{array}{l}0.0024887 \\
(0.47)\end{array}$ & $\begin{array}{l}0.0000867 \\
(0.02)\end{array}$ & $\begin{array}{l}-0.0055311 \\
(-0.85)\end{array}$ \\
\hline$G O V T$ & $\begin{array}{l}-0.1055545 * * * * \\
(-4.44)\end{array}$ & $\begin{array}{l}-0.1154642 * * * * \\
(-4.69)\end{array}$ & $\begin{array}{l}-0.1062903 * * * * \\
(-4.54)\end{array}$ & $\begin{array}{l}-0.115508 * * * * \\
(-4.66)\end{array}$ \\
\hline TERMS & $\begin{array}{l}0.0807503 * * * * \\
(3.56)\end{array}$ & $\begin{array}{l}0.0832152 * * * * \\
(3.69)\end{array}$ & $\begin{array}{l}0.0804417 * * * * \\
(3.54)\end{array}$ & $\begin{array}{l}0.081449 * * * * \\
(3.60)\end{array}$ \\
\hline LIQUID & $\begin{array}{l}-0.0069007 \\
(-1.01)\end{array}$ & $\begin{array}{l}-0.0062657 \\
(-0.89)\end{array}$ & $\begin{array}{l}-0.0068587 \\
(-1.01)\end{array}$ & $\begin{array}{l}-0.006609 \\
(-0.96)\end{array}$ \\
\hline INSTABILITY & $\begin{array}{l}-0.0184441 * * \\
(-2.31)\end{array}$ & $\begin{array}{l}-0.0165828 * * \\
(-2.04)\end{array}$ & $\begin{array}{l}-0.0185551 * * \\
(-2.32)\end{array}$ & $\begin{array}{l}-0.0171911 * * \\
(-2.12)\end{array}$ \\
\hline OPENNESS & $\begin{array}{l}0.0179564 * * * * \\
(4.67)\end{array}$ & $\begin{array}{l}0.01837 * * * * \\
(4.64)\end{array}$ & $\begin{array}{l}0.0177223 * * * * \\
(4.54)\end{array}$ & $\begin{array}{l}0.0174987 * * * * \\
(4.47)\end{array}$ \\
\hline PREMIUM & $\begin{array}{l}-0.0110377 * * * \\
(-2.64)\end{array}$ & $\begin{array}{l}-0.0108922 * * * \\
(-2.58)\end{array}$ & $\begin{array}{l}-0.0113439 * * * \\
(-2.65)\end{array}$ & $\begin{array}{l}-0.0109476 * * * \\
(-2.61)\end{array}$ \\
\hline$P C G D P$ & $\begin{array}{l}-0.00000444 * * * \\
(-2.92)\end{array}$ & $\begin{array}{l}-6.96 \mathrm{E}-06 * * * * \\
(-4.57)\end{array}$ & $\begin{array}{l}-4.37 \mathrm{E}-06 * * * * \\
(-6.15)\end{array}$ & $\begin{array}{l}-6.89 \mathrm{E}-06 * * * * \\
(-3.59)\end{array}$ \\
\hline INTERINV & $\begin{array}{l}2.38 \mathrm{E}-08 \\
(0.01)\end{array}$ & & & \\
\hline INTERHUMCAP & & $\begin{array}{l}1.65 \mathrm{E}-07 * \\
(1.89)\end{array}$ & & \\
\hline INTERINF & & & $\begin{array}{l}-8.84 \mathrm{E}-07 \\
(-0.32)\end{array}$ & \\
\hline INTERDEM & & & & $\begin{array}{l}2.60 \mathrm{E}-06 \\
(1.38)\end{array}$ \\
\hline $\begin{array}{l}R^{2} \\
N\end{array}$ & 0.3719 & 0.3771 & 0.3721 & 0.3722 \\
\hline
\end{tabular}


Table 6 (continued)

\begin{tabular}{|c|c|c|c|c|c|}
\hline CONSTANT & $\begin{array}{l}0.029835 * * * * \\
(4.96)\end{array}$ & $\begin{array}{l}0.0297138 * * * * \\
(5.20)\end{array}$ & $\begin{array}{l}0.0310608 * * * * \\
(4.99)\end{array}$ & $\begin{array}{l}0.029476 * * * * \\
(5.17)\end{array}$ & $\begin{array}{l}0.0319996 * * * * \\
(5.25)\end{array}$ \\
\hline$I N V$ & $\begin{array}{l}0.0856521 * * * * \\
(3.82)\end{array}$ & $\begin{array}{l}0.0864426 * * * * \\
(3.88)\end{array}$ & $\begin{array}{l}0.0887415 * * * * \\
(3.90)\end{array}$ & $\begin{array}{l}0.0857621 * * * * \\
(3.84)\end{array}$ & $\begin{array}{l}0.0916444 * * * * \\
(3.99)\end{array}$ \\
\hline HUMCAP & $\begin{array}{l}0.0015703 \\
(1.59)\end{array}$ & $\begin{array}{l}0.0014731 \\
(1.48)\end{array}$ & $\begin{array}{l}0.001629 \\
(1.63)\end{array}$ & $\begin{array}{l}0.0016325^{*} \\
(1.65)\end{array}$ & $\begin{array}{l}0.0017827 * \\
(1.74)\end{array}$ \\
\hline INFLATION & $\begin{array}{l}-0.0257431 * * * * \\
(-3.50)\end{array}$ & $\begin{array}{l}-0.0260241 * * * * \\
(-3.54)\end{array}$ & $\begin{array}{l}-0.0256058 * * * * \\
(-3.47)\end{array}$ & $\begin{array}{l}-0.0259708 * * * * \\
(-3.52)\end{array}$ & $\begin{array}{l}-0.0242784 * * * * \\
(-3.25)\end{array}$ \\
\hline DEMOCRACY & $\begin{array}{l}-0.0001233 \\
(-0.02)\end{array}$ & $\begin{array}{l}0.0001666 \\
(0.03)\end{array}$ & $\begin{array}{l}0.0000767 \\
(0.02)\end{array}$ & $\begin{array}{l}-0.0000499 \\
(-0.01)\end{array}$ & $\begin{array}{l}0.0006344 \\
(0.12)\end{array}$ \\
\hline GOVT & $\begin{array}{l}0.1095543 * * * * \\
(-3.78)\end{array}$ & $\begin{array}{l}-0.105583 * * * * \\
(-4.53)\end{array}$ & $\begin{array}{l}-0.106595 * * * * \\
(-4.51)\end{array}$ & $\begin{array}{l}-0.1051353 * * * * \\
(-4.50)\end{array}$ & $\begin{array}{l}-0.1149391 * * * * \\
(-4.61)\end{array}$ \\
\hline$T E R M S$ & $\begin{array}{l}0.0807778 * * * * \\
(3.56)\end{array}$ & $\begin{array}{l}0.1035216^{* * * *} \\
(2.93)\end{array}$ & $\begin{array}{l}0.0805468 * * * * \\
(3.56)\end{array}$ & $\begin{array}{l}0.0809099 * * * * \\
(3.57)\end{array}$ & $\begin{array}{l}0.0836443 * * * * \\
(3.69)\end{array}$ \\
\hline LIQUID & $\begin{array}{l}-0.0065453 \\
(-0.94)\end{array}$ & $\begin{array}{l}-0.0066815 \\
(-0.98)\end{array}$ & $\begin{array}{l}-0.0129592 \\
(-1.18)\end{array}$ & $\begin{array}{l}-0.0068369 \\
(-1.01)\end{array}$ & $\begin{array}{l}-0.0074391 \\
(-1.07)\end{array}$ \\
\hline INSTABILITY & $\begin{array}{l}-0.0186995 * * * \\
(-2.33)\end{array}$ & $\begin{array}{l}-0.018435^{* *} \\
(-2.30)\end{array}$ & $\begin{array}{l}-0.0185461 * * \\
(-2.31)\end{array}$ & $\begin{array}{l}-0.0229689^{*} \\
(1.65 \mathrm{E}-06)\end{array}$ & $\begin{array}{l}-0.0176572 * * \\
(-2.18)\end{array}$ \\
\hline OPENNESS & $\begin{array}{l}0.0178216 * * * * \\
(4.58)\end{array}$ & $\begin{array}{l}0.0175439 * * * * \\
(4.53)\end{array}$ & $\begin{array}{l}0.0182996 * * * * \\
(4.68)\end{array}$ & $\begin{array}{l}0.0180408 * * * * \\
(4.69)\end{array}$ & $\begin{array}{l}0.0121056^{*} \\
(2.08)\end{array}$ \\
\hline PREMIUM & $\begin{array}{l}-0.0110032 * * * \\
(-2.63)\end{array}$ & $\begin{array}{l}-0.0112022 * * * \\
(-2.68)\end{array}$ & $\begin{array}{l}-0.0108172 * * * \\
(-2.57)\end{array}$ & $\begin{array}{l}-0.0108523 * * * \\
(-2.59)\end{array}$ & $\begin{array}{l}-0.0112932 * * * \\
(-2.68)\end{array}$ \\
\hline$P C G D P$ & $\begin{array}{l}-4.54 \mathrm{E}-06 * * * * \\
(-5.40)\end{array}$ & $\begin{array}{l}-4.37 \mathrm{E}-06 * * * * \\
(-6.33)\end{array}$ & $\begin{array}{l}-4.91 \mathrm{E}-06 * * * * \\
(-4.93)\end{array}$ & $\begin{array}{l}-4.49 \mathrm{E}-06 * * * * \\
(-6.41)\end{array}$ & $\begin{array}{l}-5.74 \mathrm{E}-06 * * * * \\
(-4.84)\end{array}$ \\
\hline INTERGOVT & $\begin{array}{l}1.96 \mathrm{E}-06 \\
(0.24)\end{array}$ & & & & \\
\hline INTERTERMS & & $\begin{array}{l}-8.21 \mathrm{E}-06 \\
(-0.84)\end{array}$ & & & \\
\hline INTERLIQ & & & $\begin{array}{l}8.92 \mathrm{E}-07 \\
(0.69)\end{array}$ & & \\
\hline INTERINST & & & & $\begin{array}{l}1.65 \mathrm{E}-06 \\
(0.43)\end{array}$ & \\
\hline INTEROPEN & & & & & $\begin{array}{l}1.45 \mathrm{E}-06 \\
(1.39)\end{array}$ \\
\hline $\begin{array}{l}R^{2} \\
N\end{array}$ & 0.3720 & 0.3730 & 0.3721 & 0.3722 & 0.3730 \\
\hline
\end{tabular}


Table 6 (continued)

$\begin{array}{ll}\text { CONSTANT } & 0.0298322 * * * * \\ & (5.23) \\ \text { INV } & 0.0901599^{* * * *} \\ & (4.02) \\ \text { HUMCAP } & 0.0015529 \\ & (1.58) \\ \text { INFLATION } & -0.0249731^{* * * *} \\ & (-3.41) \\ \text { DEMOCRACY } & 0.0001089 \\ & (0.02) \\ \text { GOVT } & -0.1165666^{* * * *} \\ & (-4.82) \\ \text { TERMS } & 0.0763674 * * * * \\ & (3.36) \\ \text { LIQUID } & -0.0063684 \\ & (-0.93) \\ \text { INSTABILITY } & -0.0186363 * * \\ & (-2.33) \\ \text { OPENNESS } & 0.0165205^{* * * *} \\ & (4.20) \\ \text { PREMIUM } & -0.003628 \\ & (-0.06) \\ \text { PCGDP } & -4.33 \mathrm{E}-06^{* * * * *} \\ & (-6.30) \\ \text { INTERPREM } & -3.62 \mathrm{E}-06^{*} \\ R^{2} & (-1.70) \\ N & 0.3765 \\ & \end{array}$


Table 7

Summary results

\begin{tabular}{|l|l|l|}
\hline & Positive Sign & Negative Sign \\
\hline Income & $\begin{array}{l}\text { KAPW, HUMCAP, OPEN, } \\
\text { DEMOCRACY, LIQUID }\end{array}$ & PREMIUM, LIQUID \\
\hline Growth & INVGDP, PREMIUM, & PREMIUM, GOVT, \\
& TERMS, OPEN, & INSTABILITY, INFLATION \\
& INSTABILITY, & \\
& DEMOCRACY, & \\
\hline
\end{tabular}


Table 8

Per capita income, trade and trade shocks

$\begin{array}{lll}\text { Percentile (200) } & \text { Upper Income level } & (X+M) / G D P \\ 0-0.2 & 1589.20 & 0.6282 \\ 0.2-0.4 & 3847.132 & 0.8394 \\ 0.4-0.6 & 6732.241 & 0.8378 \\ 0.6-0.8 & 14,589.78 & 97.59 \\ 0.8-1 & 39,656.49 & 98.80 \\ & & \\ \text { Percentile (1990) } & \text { Upper Income level } & \text { Mean, TERMS, 1990-1995 } \\ 0-0.2 & 914.6 & -0.01296 \\ 0.2-0.4 & 2092.6 & 0.0035436 \\ 0.4-0.6 & 3994.2 & -0.003544 \\ 0.6-0.8 & 10,416.6 & -0.003636 \\ 0.8-1 & 32,014 & -0.005315\end{array}$

Sources: PWT v6.1 (top), Barro-Lee (bottom) 